\title{
Chart Datum and Bathymetry Correction to Support Managing Coral Grouper in Lepar and Pongok Island Waters, South Bangka Regency
}

\author{
Sudirman Adibrata1,2*, Fredinan Yulianda ${ }^{3}$, Mennofatria Boer ${ }^{3}$, and I Wayan Nurjaya ${ }^{4}$ \\ 1 Program of Coastal and Marine Resource Management, Bogor Agricultural University \\ $\mathrm{Jl}$. Agatis Campus IPB Darmaga Bogor 16680, Indonesia \\ 2Program of Aquatic Resource Management, Faculty Agriculture, Fishery and Biology, Bangka Belitung Unversity \\ J. Balunijuk Merawang District, Bangka, Bangka Belitung, Indonesia \\ ${ }^{3}$ Department of Aquatic Resource Management, Fisheries and Marine Science Faculty, \\ Bogor Agricultural University; J. Agatis Campus IPB Darmaga Bogor 16680, Indonesia \\ ${ }^{4}$ Department of Marine Science and Technology, Fisheries and Marine Science, \\ Bogor Agricultural University, Jl. Agatis Campus IPB Darmaga Bogor 16680, Indonesia \\ Email: sadibrata@gmail.com
}

\begin{abstract}
Corrected bathimetry data is highly required to improve the quality of sea floor map, for a range of purposes including coastal environmental monitoring and management. This research was aimed to know chart datum values used for correctting bathymetry data at Bar-cheeked coral trout grouper (Plectropomus maculates) fishing ground in Lepar and Pongok Island waters 02.57'00"S and 106.50'00"E and 02.53'00"S and 107'03'00"E, respectively, South Bangka Regency, Indonesia. The study was carried out from November 2016 to October 2017, tidal data used for 15 days from September 16-30, 2017 using simple random sampling technique with the total of 845 points of measurements. To calculate tyde harmonic constituents values this study employed admiralty method resulting 10 major components. Results of this research indicated that harmonic coefficient values of $\mathrm{M} 2, \mathrm{M} 2, \mathrm{~S} 2, \mathrm{~N} 2, \mathrm{~K} 1,01, \mathrm{M} 4, \mathrm{MS} 4, \mathrm{~K} 2$, and $\mathrm{P} 1$, were $0.0345 \mathrm{~m}, 0.0608 \mathrm{~m}$, $0.0276 \mathrm{~m}, 0.4262 \mathrm{~m}, 0.2060 \mathrm{~m}, 0.0119 \mathrm{~m}, 0.0082 \mathrm{~m}, 0.0164 \mathrm{~m}$, and $0.1406 \mathrm{~m}$, respectively. Values of mean sea level, chart datum, and $F$, were $0.9620 \mathrm{~m}, 0.0500 \mathrm{~m}$, and $0.0664 \mathrm{~m}$, respectively, with diurnal type ( $F=$ 6.64). Correcting bathymetry values of surveyed location results a deviation about $1.2 \mathrm{~m}$ in depth. The calculated chart datum as well as corrected bathymetry provides information that can be used as vertical refrerence datum for generating sea floor map for determining the fishing ground area of bar-cheeked coral trout grouper. Fishing depth usually ranges between 4.2 and $40.8 \mathrm{~m}$. Average water depth in the fishing ground ranged from 14.7 to $22.5 \mathrm{~m}$.
\end{abstract}

Keywords: bar-cheeked coral trout grouper, chart datum, bathymetry, fishing ground, tides.

\section{Introduction}

Fishing ground of Serranidae Family such as bar-cheeked coral trout grouper (Plectropomus maculatus Bloch 1790) (Allen, 1999; Froese and Pauly, 2017) in small islands is usually located in certain water depth where coral reefs are still found. There is always a clear relationship between demersal fish distribution and water depth (Blaber et al., 1994). Fish from Serranidae Family are discovered in coral reefs areas (Tupper, 2007) in seven $m$ depth, Garner and Patterson (2015) observed coral reef fish in $<40 \mathrm{~m}$ depth, Froese and Pauly (2017) also observed fish in depth of 5-100 $\mathrm{m}$, therefore a better understanding of bathymetry data becomes an important part of trap fishing operation as it can help increase catch yields. More importantly for safety reason, the allowable healthy depth layer (diving depth) for fishermen was in general limited to $40 \mathrm{~m}$ depth. Hydrographic surveying relating to fishermen works are usually conducted to localize safe diving sports, coral reefs location in good and bad condition, location for no sailing tracks, and safety location for setting traps in the water column. Fishermen need marine information not only for their safety boat navigation but also for setting their fish traps in order to avoid loss, and one of hydrographic coverage is coastal areas management by mapping bathymetry as an important input for fishery industry (IHO, 2005). Fishermen can work easily because of accurate bathymetry information such as effective diving duration, avoiding fish traps lost and catch, and abilities in identifying and marking fishing grounds. 
Corrected bathymetry is needed by fishermen, especially in water depth accuracy related to diving duration and safety. The listed bathymetry in Global Positioning System-map (GPSmap) has to be corrected previously for making sea maps consideration in order to become useful information. Correction of bathymetry data in real time should be conducted on sea level change, measurement of sensors, and survey ship draft changes (IHO, 2005). To understand fluctuation of sea level in coastal areas, observing variables of tides is conducted spatially (Tamisiea et al., 2014). Tides is an up and down process of sea level periodically that is resulted by gravitation of space objects mainly the sun and the moon towards water mass in the earth (Pugh, 1996). Mean sea level in Newlyn was taken by tide gauge device as long as six years (Bradshaw et al., 2016). Fluctuation of sea level can be predicted from harmonic constant values of tidal driving forces in the research location by using specific harmonic analysis method (Adibrata, 2007). Measuring bathymetry by means of acoustic devices is carried out by locating sensors such as transducer in the specific depth below sea surface during survey period. Integration of sensors (GPS and single beam echo transducer) in a marine drone at shallow waters $(0-20 \mathrm{~m})$ increases performance of the device and accuracy of bathymetry survey than boat traditional survey (Giordano et al., 2016). Other researches, bathymetri measurement used fish finder GPS and pocket GPS (Nandiko, 2017), in modernly combination fish finder and drone boat (Yamasaki et al., 2017).

The United States National Ocean Service (NOS) uses a Chart Datum which is defined in some areas of mixed tides as the mean of the lower of the two low waters in each day (MLLW), in some semidiurnal tidal areas as mean low water springs (MLWS), and elsewhere as the lowest possible low water, chart datum is defined in terms of the local tidal characteristics (Pugh, 1996), chart datum is used in sea maps and tides prediction is used for a reference of zero depth that exceeds the lowest sea level astronomically applying locally. It functionates (IHO, 2017) as a field reference for selected all depths from the lowest water depth under normal meteorological in tidal areas. This chart datum calculation is related to the application of harmonic constant values of tides. Analysis of harmonic tides is applied for determining chart datum in Jijel Algeria (Rami et al., 2016), in Karampuang Island (Adibrata, 2007). The chart datum value should be referenced toward a bench mark in order to be a datum referenced point of tides in use. The more coordinate and bathymetry data is collected, the better data will be good for mapping sea bottom of a specific location. Recorded bathymetry coordinates when fishermen go fishing bar-cheeked coral trout grouper are going to provide fishing ground information for mapping fishery management of the grouper. Therefore, calculation of chart datum and corrected bathymetry of fishing grounds become important information to be researched leading up to sustainable fishery management of grouper for fishermen from Pongok Island, South Bangka Regency, Indonesia. This research was aimed to know chart datum for calculating corrected bathymetry and averaged bathymetry for managing the fishing ground of barcheeked coral trout grouper.

\section{Materials and Methods}

The research was conducted from November 2016 to October 2017 including bathymetric and tide measurements. Tides were measured both manually using tide staff and automatically using Kalesto Automatic Floating Tide Gauge facilitated by Bangka Belitung Ocean Science and Technology (BOST) Center. Tide were recorded from September 16-30, 2017, (Ongkosongo and Suyarso, 1989) stated that (15 days) with one hour interval in every 24 hours. Furthermore, tidal sampling location was carried out automatically in Sadai by its coordinate at $03^{\circ} 03^{\prime} 18.67^{\prime \prime S}$ and $106^{\circ} 44^{\prime} 15.33^{\prime \prime} E$. Observations were carried out in both waters, around Lepar Island and Pongok Island, South Bangka Regency - Indonesia with coordinates at 02057'00"S and 106 50 '00"E and 02.53'00"S and 107'03'00"E, respectively. Tidal sampling location was carried out manually in Celagen Island at $02^{\circ} 52 ' 26.40 " S$ and $107^{\circ} 00^{\prime} 58.50 " \mathrm{E}$.

Field survey coordinates bathymetry used simple random sampling method is chosen in such a way that every set of individuals coordinate has an equal chance to be in the selected of bathymetry coordinates sample that through following fisherman boats to save costs. Fishermen works of diving in setting and taking up fish traps were about 1800 coordinate spots every year (about 15 to 25 days per month, and 5 to 10 spots per day). Tools and aquipment were used in this research consisted of (1) tidal gauge and Bench Mark in Celagen Island such as scaled pole, torch, waterpass, handwatch, handheld GPS Garmin, and an automatic tidal gauge in Sadai namely Kalesto Automatic Floating Tide Gauge; (2) bathymetry measurement aquipment such as a set of GPSmap 585 Garmin, camera, and \pm 5 GT boat.

Tidal data were analyzed using harmonic analysis by utilizing admiralty method (Ongkosongo and Suyarso, 1989). Numeric values of the surveyed tidal data then were tabulated, created graphs and conducted smoothing process. Tools for 
analysis such as Microsoft Office Software, ArcGIS 10.3.1, Tides Prediction V1.002 Software (Witjaksono et al., 1989), and Indonesian waters environmental map. Results of the last process than were analyzed throughout some steps until resulting tidal harmonic constants (Table 1.) such as M2, S2, N2, K1, 01, M4, MS4, K2, dan P1. The admiralty method had three steps namely separating main components of tidal data according to daily process, montly process, and obtaining constants values of amplitude $(A$ in $\mathrm{cm})$ and phase value ( $\mathrm{g}$ in degree). These constants (harmonic constituents) were employed for Chart Datum (CD) calculation and tides prediction when measuring bathymetry for correcting bathymetry.

Values of Mean Sea Level (MSL) were identified from So value, while CD formula (2) refered to Pugh (1996), CD formula (2) refered to Adibrata (2007), CD formula $(1,2,3,4,5)$ refered to Pradipta et al. (2015) as following:

1. Lowest Possible Low Water. This datum is used in France for making its sea maps.

$$
C D=S o-1.2(M 2+S 2+K 2)
$$

2. Indian Spring Low Water (ISWL), this datum is used for investigating tides of India.

$$
C D=S o-(M 2+S 2+K 1+01)
$$

3. Mean Spring Low Water (MSLW) is an averaged lowest water at full moon $C D=S o-(M 2+S 2)$.

4. Chart Datum Dishidros is a chart datum that is defined by Hidro-Oceanography Naval Service of Indonesia (Dishidros) using for a referenced sea maps in Indonesia. $C D=S o-\sum A i$.

This formula will be used for tidal analysis locally in Indonesia especially at the study location, $\mathrm{Ai}$ is included 01, P1, K1, M2, N2, S2, K2.

5. Chart Datum according to the definition by International Hidrogphy Organization (IHO), that is based on the determination of a field as low as possible. $C D=S o-\sum A i$

where So is a mean sea level (MSL), CD is a chart datum position, and other five items amplitudes of tides such as M2 M2, S2, K1, K2, 01. An amplitude of seven components of tides that is used for Dishidros such as 01, P1, K1, M2, N2, S2, K2. Ai $\mathrm{IHO}$ is an amplitude of tide component that is resulted by $\mathrm{IHO}$ analysis.

By consideration that measuring bathymetry is conducted locally in Indonesia territorial waters, that $C D$ value is utilized from Dishidros. The relative importance of the diurnal and semidiurnal tidal constituents is sometimes expressed in terms of a Form Factor (Pugh, 1996), for the safety of fishing boats when leaning: $F=(\mathrm{K} 101 /(\mathrm{M} 2+\mathrm{S} 2)$. where $\mathrm{F}$ is a formzahl number, and those four other items are amplitudes of tidal components. For $0<\mathrm{F} \leq 0.25$ is categorized semi-diurnal; $0.25<\mathrm{F} \leq 1.5$ is mixing tends to be semi-diurnal; $1.5<\mathrm{F} \leq 3$ is grouped into mixing tends to be diurnal; and $\mathrm{F}>3$ is diurnal.

In particular the semidiurnal tides are slightly reduced when the diurnal tides are greatest, also, the shallow water constituents conspire to reduce the extreme ranges, the values of Highest Astronomical Tide and Lowest Astronomical Tide are usually determined by examination of at least five years of predictions, or by making predictions for years of known astronomical extremes. Chart Datum is defined locally to be close to the Lowest Astronomical Tide level (Pugh, 1996). It means the $C D$ value has to be under the lowest tide that might happen. Hence, it is needed tidal prediction to know the real sea surface level during bathymetry measuring surveys. Information from measuring bathymetry such as coordinates, bathymetry values, and time, should be corrected towards CD value and the position of GPSmap 585 Garmin transducer. Ilustration of measuring tide and bathymetry in real time needs sea surface levelduring conducted bathymetry survey (Figure 1.). The corrected bathymetry value is calculated the following formula. $\mathrm{Bk}=\mathrm{Bp}-\mathrm{tr}+\mathrm{Bsk}-\mathrm{CD}$

Table 1. Harmonic constants of tides

\begin{tabular}{lcl}
\hline \multicolumn{1}{c}{ Komponents of tides } & Symbol & \multicolumn{1}{c}{ Annotation } \\
\hline Semi-diurnal & M2 & Main component of semi-diurnal lunar \\
& S2 & Main component of semi-diurnal solar \\
N2 & Component of lunar as a result of moon distant variation montly \\
Diurnal & K1 & Component of soli-lunar as a result of declenation change \\
& O1 & Main component of diurnal lunar \\
Shallow Water & P1 & Main component of diurnal solar \\
& M4 & Main component of shallow water \\
& MS4 & Main component of shallow water
\end{tabular}

Source: Adibrata, 2007 


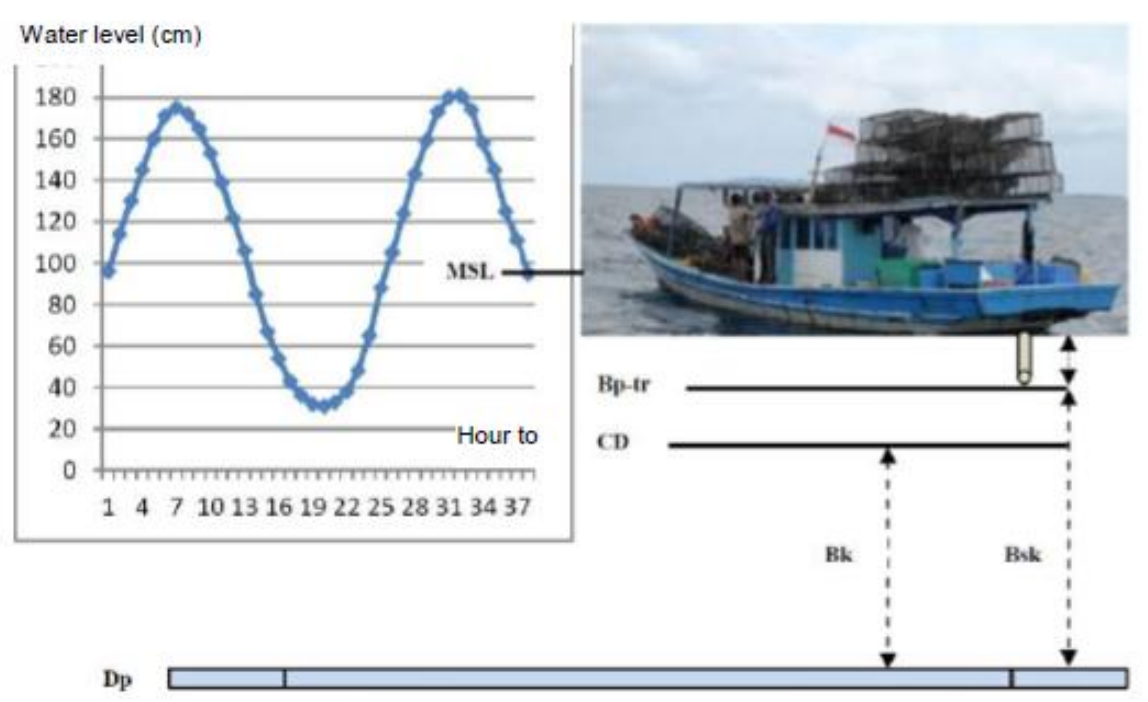

Figure 1. Sea Surface and Bathymetry Measurement

where Bk is a corrected bathymetry, MSL is mean sea level, Bp-tr is a value of depth from sea surface to the edge of transducer, Bsk is a bathymetry value before being corrected in measuring hours during surveys, $C D$ is a chart datum position, and $D p$ is a sea bottom.

Interpolating bathymetry data on scaled pole was conducted for measuring hours during surveys that was improper with hours data of measuring tides by using the following formula: $X(a: b)=X(a)+$ $((X(a+1)-X(a)) / 60) * b$. where $a$ is in hour unit, $b$ is in minute unit, and $X(a: b)$ is a value of sea level high at $X(\mathrm{~cm})$ tidal pole on hour $a$ and minute $b, X(a)$ $(\mathrm{cm})$ is an exact bathymetry value on hour $\mathrm{a}, \mathrm{X}(\mathrm{a}+1)$ $(\mathrm{cm})$ is a value of bathymetry on the next hour.

\section{Results and Discussion}

Figure 2 decsribes the distribution spots for fishing grounds of bar-cheeked coral trout grouper. The fishing ground coordinate is the location of the traps that can be repeated every two months. Bathymetry at these coordinates must have a high degree of accuracy to make it easier for divers to estimate the depth that is still capable of diving.

Calculating tidal harmonic through admiralty method results constant values as listed in Table 2 . After conducting analysis to generate $C D$ values based on formulas in the part of methodology, it results values as seen in the Table 3 . The $C D$ value of the calculation results is $5 \mathrm{~cm}(0.05 \mathrm{~m})$ and Pushidrosal is $15 \mathrm{~cm}(0.15 \mathrm{~m})$. The $C D$ value from the calculation is $5 \mathrm{~cm}$ and Pushidrosal is $15 \mathrm{~cm}$. This value is not much different if it is converted in meters.
Furthermore, $\mathrm{F}$ value as big as 6.64 that is categorized into type diurnal, compared with the prediction data from Pushidrosal, it was found that the $F$ value was 7.6. The $F$ value of the calculation results and Pushidrosal shows the diurnal type in which there is one high tide and one low tide in 24 hours.

The results of measurements of bathymetry and coordinates of the pots in the coral reef area during fishing, the time when recording bathymetry data is not the same as the time when tidal measurements. This must be done by interpolation referring to the value of sea level in the nearest hours. Some examples of corrected bathymetry data representing 12 months can be seen as shown in Table 4. Results of corrected bathymetry data for 12 months from fishing areas are listed in Table 5.

Corrected bathymetry data above can be adopted to supplement the data on the sea map. Function of sea maps in every country is for sea navigation and information source relating to hydrography for contruction engineers in offshore development, dredging contractors, oceanographers, defense department, coastal managers, and others (IHO, 2017). How important the value of corrected bathymetry is for the benefit of coastal management, including for fishermen. Hydrography is a branch of applied science that scopes measuring and figuring sea levels and coastal areas for main navigation purposes and other all marine activities, including offshore activities, researches, environmental protection, and prediction services (IHO, 2005). For fishermen who catch the barcheeked coral trouth grouper in the coral reef ecosystem, bathymetry and coordinates are the initial capital that is very important for the development of their business. 
ILMU KELAUTAN Desember 2018 Vol 23(4):179-186

Table 2. Tidal Constant Values of Celagen Island on September 16-30, 2017

\begin{tabular}{|c|c|c|c|c|c|c|c|c|c|c|}
\hline Konstants & SO & M2 & S2 & N2 & K1 & 01 & M4 & MS4 & $\mathrm{K} 2$ & P1 \\
\hline $\begin{array}{c}A(\mathrm{~cm}) \\
\mathrm{g}^{\circ}\end{array}$ & 96.20 & $\begin{array}{c}3.45 \\
68.24 \\
\end{array}$ & $\begin{array}{c}6.08 \\
74.23 \\
\end{array}$ & $\begin{array}{c}2.76 \\
111.54\end{array}$ & $\begin{array}{c}42.62 \\
185.96 \\
\end{array}$ & $\begin{array}{l}20.60 \\
70.84\end{array}$ & $\begin{array}{c}1.19 \\
144.20\end{array}$ & $\begin{array}{c}0.82 \\
232.51\end{array}$ & $\begin{array}{c}1.64 \\
74.23\end{array}$ & $\begin{array}{r}14.06 \\
185.96\end{array}$ \\
\hline $\begin{array}{c}\text { Pushidrosal } \\
\text { A (cm) } \\
\mathrm{g}^{\circ}\end{array}$ & 170 & $\begin{array}{c}8 \\
293\end{array}$ & $\begin{array}{c}7 \\
335\end{array}$ & - & $\begin{array}{c}72 \\
221\end{array}$ & $\begin{array}{c}42 \\
281\end{array}$ & - & - & - & $\begin{array}{c}26 \\
221\end{array}$ \\
\hline
\end{tabular}

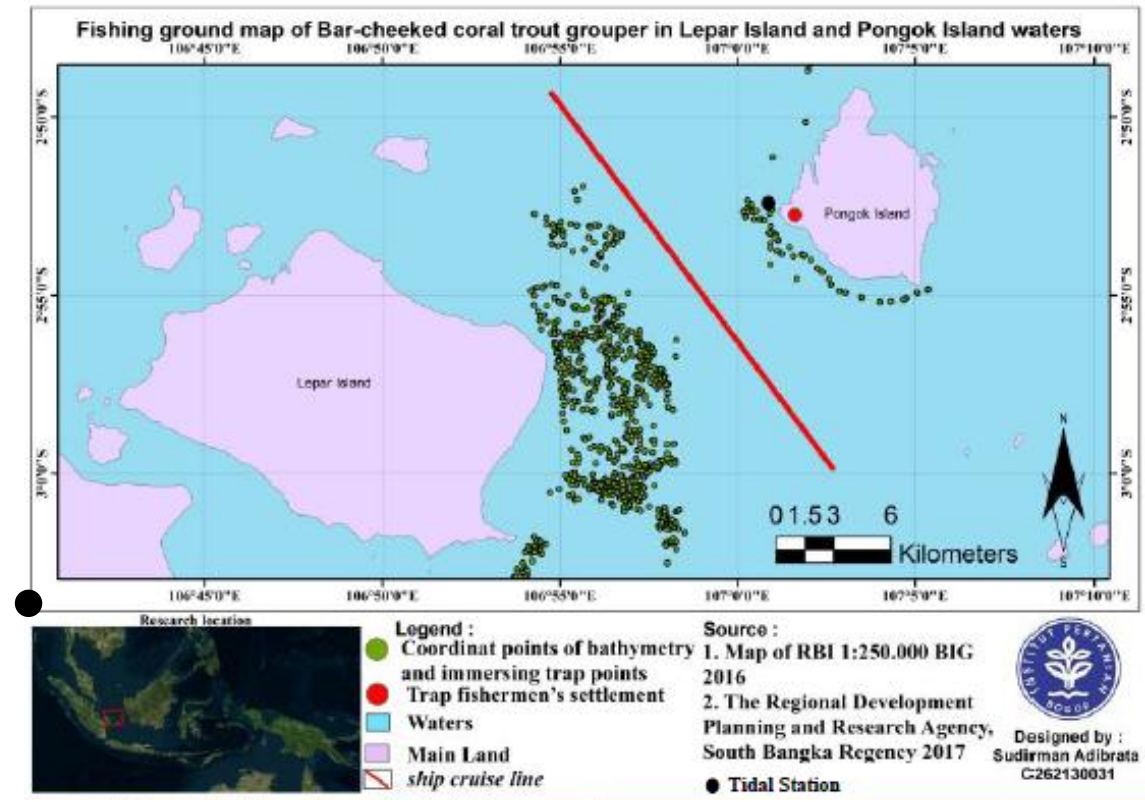

Figure 2. Map of bathymetry spots in fishing ground. Tidal station in Celagen Island (107'0 01'04,4" E and 02 52' 33,2" S)

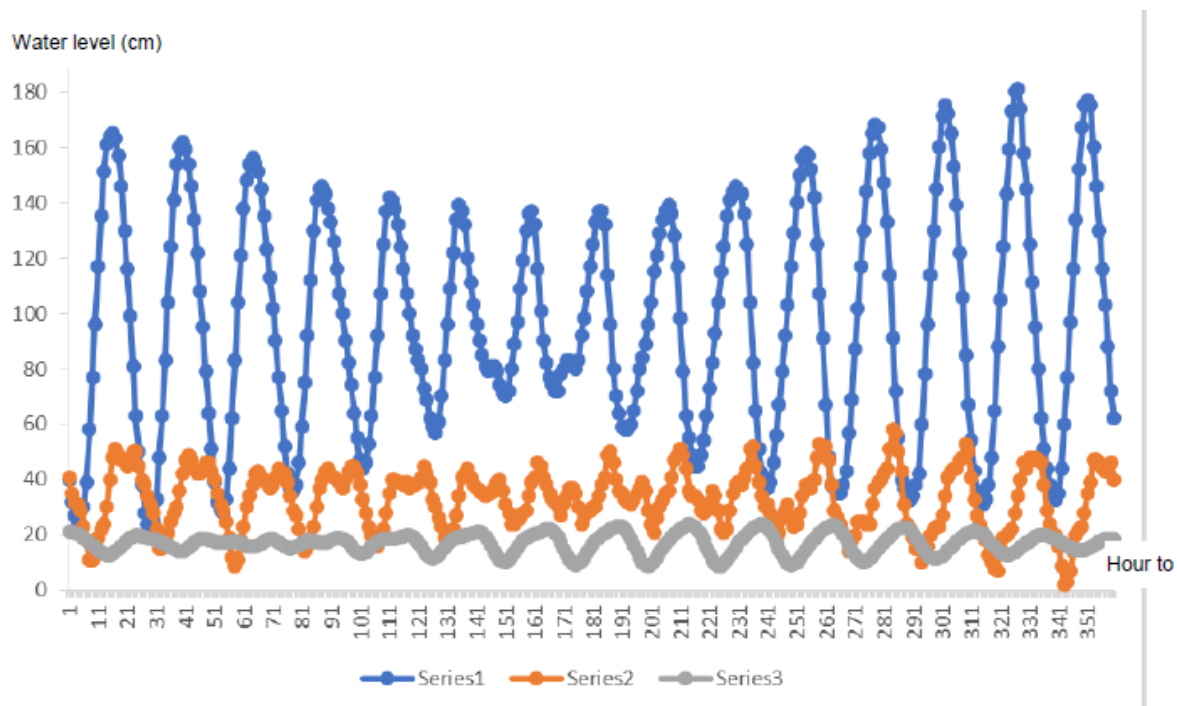

Figure 3. Tidal Graphic of Celagen Island

Note. $-=$ Survey of tidal in Sadai, BOST Center; $-=$ Survey of tidal in Celagen Island; - $=$ Prediction data from Pushidrosal TNI AL Indonesia

Depiction of bathymetry spots (Figure 2.) is fishing grounds of the bar-cheeked coral trouth grouper with pots fishing gear by fishermen in Pongok island, South Bangka Regency. An accurate bathymetry survey as a part of hydrography scope surely can not be separated from calculating amplitudes of tidal components in determining chart datum as a referenced datum of sea depth. 
Bathymetry survey in this research is intended as a process of measuring depths for figuring sea bottom surface in fishing grounds of coral reefs areas. Based on RI Act No. 4 of 2011, article 13, paragraph 4 states that in coastal environmental maps and national marine environmental maps, coastline is circumscribed based on sea level at low tide. On this basis, there should be a basic reference field used in making standard maps of sea that is well know as chart datum. Locally basic reference field is utilized in avoiding bias during extreme condition of sea level for specific purposes for instance on what hours and dates the highest and the lowest values of sea level high condition. Extreem condition of sea level ussualy happens on full moon (spring tide) and the lowest tide on neap tide. Referring to the above conditions based on the data when spring tides occurwhen position of earth, moon, and sun are parallel to form a perpendicular angle, usually happening on $1 / 4$ and $3 / 4$ moon position. In the Figure 2 is clearly seen that spring tide condition happened on second week or fourth week or around September 16-30, 2017, and neap tide happened on third week or around September 21-23, 2017.

The value of chart datum as analysis result using Dishidros formula based on harmonic constant calculation of tide is about $5.00 \mathrm{~cm}(0.05$ $\mathrm{m})$ from tides scale pole. For future research needs,

Table 3. Chart Datum Values

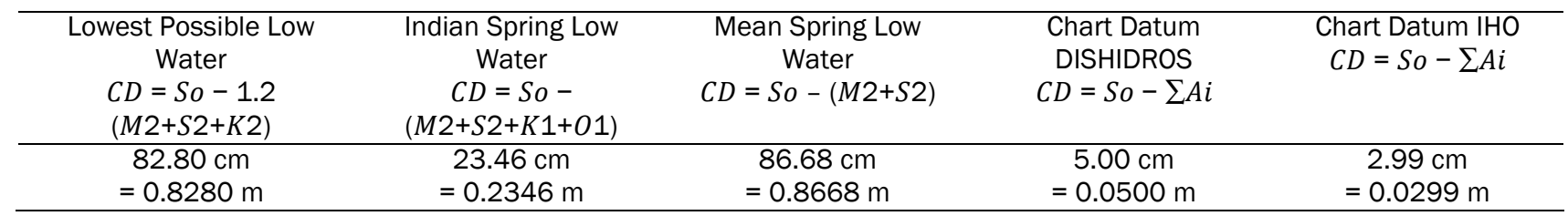

Table 4. Coordinates and Corrected Bathymetry Values

\begin{tabular}{|c|c|c|c|c|c|c|c|c|c|}
\hline $\begin{array}{l}\text { Coordinate } \\
\text { (1) }\end{array}$ & $\begin{array}{c}\text { Hour / Date } \\
\text { (2) }\end{array}$ & $\begin{array}{l}\text { Bsk } \\
(\mathrm{m}) \\
(3) \\
\end{array}$ & $\begin{array}{c}\text { Bp-tr } \\
(\mathrm{m}) \\
(4) \\
\end{array}$ & $\begin{array}{c}\mathrm{X}(\mathrm{a}: \mathrm{b}) \\
(\mathrm{cm}) \\
(5) \\
\end{array}$ & $\begin{array}{c}\mathrm{CD} \\
(\mathrm{cm}) \\
(6) \\
\end{array}$ & $\begin{array}{c}\Delta \mathrm{p}-\mathrm{CD} \\
(\mathrm{cm}) \\
(7=5-6)\end{array}$ & $\begin{array}{c}\Delta \mathrm{p}-\mathrm{CD} \\
(\mathrm{m}) \\
(8=(7) / 100)\end{array}$ & $\begin{array}{c}\mathrm{Bk} \\
(\mathrm{m}) \\
(9=3+4-8) \\
\end{array}$ & $\begin{array}{c}\text { Deviation } \\
(\mathrm{m}) \\
(10=3-9)\end{array}$ \\
\hline $\begin{array}{l}106.92072 \mathrm{E} \\
-2.96589 \mathrm{~S}\end{array}$ & $\begin{array}{l}10.00 \text { am } \\
\text { Nov } 19,2016\end{array}$ & 11.20 & 0.50 & 137.60 & 5.00 & 132.60 & 1.33 & 10.40 & 0.80 \\
\hline $\begin{array}{l}107.02451 \mathrm{E} \\
-2.89430 \mathrm{~S}\end{array}$ & $\begin{array}{l}11.00 \mathrm{am} \\
\text { Dec 17, } 2016\end{array}$ & 15.10 & 0.50 & 160.80 & 5.00 & 155.80 & 1.56 & 14.00 & 1.10 \\
\hline $\begin{array}{l}106.93233 \mathrm{E} \\
-3.00475 \mathrm{~S}\end{array}$ & $\begin{array}{l}11.30 \mathrm{am} \\
\operatorname{Jan} 15,2017\end{array}$ & 11.90 & 0.50 & 160.40 & 5.00 & 155.40 & 1.55 & 10.80 & 1.10 \\
\hline $\begin{array}{l}106.91572 \mathrm{E} \\
-2.89347 \mathrm{~S}\end{array}$ & $\begin{array}{l}10.00 \text { am } \\
\text { Feb } 9,2017\end{array}$ & 19.90 & 0.50 & 133.50 & 5.00 & 128.50 & 1.28 & 19.10 & 0.80 \\
\hline $\begin{array}{l}106.92339 \mathrm{E} \\
-2.95203 \mathrm{~S}\end{array}$ & $\begin{array}{l}10.00 \text { am } \\
\text { Mar 12, } 2017\end{array}$ & 16.60 & 0.50 & 130.50 & 5.00 & 125.50 & 1.26 & 15.80 & 0.80 \\
\hline $\begin{array}{l}106.91980 \mathrm{E} \\
-2.93969 \mathrm{~S}\end{array}$ & $\begin{array}{l}09.30 \text { am } \\
\text { Apr } 8,2017\end{array}$ & 15.10 & 0.50 & 112.60 & 5.00 & 107.60 & 1.08 & 14.50 & 0.60 \\
\hline $\begin{array}{l}106.95389 \mathrm{E} \\
-2.96244 \mathrm{~S}\end{array}$ & $\begin{array}{l}10.30 \text { am } \\
\text { May } 10,2017\end{array}$ & 21.20 & 0.50 & 82.20 & 5.00 & 77.20 & 0.77 & 20.90 & 0.30 \\
\hline $\begin{array}{l}106.96533 \mathrm{E} \\
-3.01747 \mathrm{~S}\end{array}$ & $\begin{array}{l}09.20 \text { am } \\
\text { Jun } 5,2017\end{array}$ & 22.30 & 0.50 & 85.10 & 5.00 & 80.10 & 0.80 & 22.00 & 0.30 \\
\hline $\begin{array}{l}107.00480 \mathrm{E} \\
-2.87772 \mathrm{~S}\end{array}$ & $\begin{array}{l}09.10 \text { am } \\
\text { Jul } 17,2017\end{array}$ & 22.30 & 0.50 & 70.80 & 5.00 & 65.80 & 0.66 & 22.10 & 0.20 \\
\hline $\begin{array}{l}106.96883 \mathrm{E} \\
-3.03142 \mathrm{~S}\end{array}$ & $\begin{array}{l}11.48 \text { am } \\
\text { Aug } 30,2017\end{array}$ & 24.90 & 0.50 & 90.00 & 5.00 & 85.00 & 0.85 & 24.50 & 0.40 \\
\hline $\begin{array}{l}106.96083 \mathrm{E} \\
-2.94314 \mathrm{~S}\end{array}$ & $\begin{array}{l}13.25 \mathrm{pm} \\
\text { Sep } 28,2017\end{array}$ & 22.40 & 0.50 & 173.80 & 5.00 & 168.80 & 1.69 & 21.20 & 1.20 \\
\hline $\begin{array}{l}106.90086 \mathrm{E} \\
-3.04456 \mathrm{~S} \\
\end{array}$ & $\begin{array}{l}12.30 \mathrm{pm} \\
\text { Oct } 28,2017\end{array}$ & 16.80 & 0.50 & 146.70 & 5.00 & 141.70 & 1.42 & 15.90 & 0.90 \\
\hline
\end{tabular}

Table 5. Monthly Corrected Bathymetry Values

\begin{tabular}{|c|c|c|c|c|c|c|c|c|c|c|c|c|}
\hline \multirow[t]{2}{*}{ Annotation } & \multicolumn{12}{|c|}{ Months } \\
\hline & Nov & Dec & Jan & Feb & Mar & Apr & May & Jun & Jul & Aug & Sep & Oct \\
\hline Min (m) & 7.00 & 7.40 & 9.90 & 10.50 & 8.90 & 13.30 & 11.10 & 10.30 & 8.30 & 4.20 & 10.40 & 7.30 \\
\hline $\operatorname{Max}(\mathrm{m})$ & 23.90 & 33.50 & 24.20 & 25.20 & 23.90 & 27.40 & 26.00 & 40.80 & 26.40 & 27.70 & 29.80 & 26.10 \\
\hline Average (m) & 14.70 & 16.20 & 16.70 & 18.40 & 17.70 & 20.70 & 19.30 & 20.40 & 18.10 & 19.30 & 22.50 & 15.70 \\
\hline
\end{tabular}


values of mean sea level (MSL) and chart datum are $96.20 \mathrm{~cm}(0.96 \mathrm{~m})$ and $5.00 \mathrm{~cm}(0.05 \mathrm{~m})$, respectively, are referenced to the Bench Mark (BM) of Celagen Island on the coordinate of $02^{\circ} 52^{\prime} 26.4^{\prime \prime S}$ and $107^{\circ} 00^{\prime} 58.5^{\prime \prime} \mathrm{E}$ with BM high is about $50.00 \mathrm{~cm}(0.50 \mathrm{~m})$ above ground level or $315.50 \mathrm{~cm}$ (3.16 m) from tides scale pole. The BM value is equal to $219.30 \mathrm{~cm}(2.19 \mathrm{~m})$ from $\mathrm{MSL}$ value or $310.50 \mathrm{~cm}(3.11 \mathrm{~m})$ from chart datum value. The corrected bathymetry will be significant for other research as there is a work of calculating water volume of a bay, volume of land extension accurately in the case of reclamation, volume of dredging in the case of deeping groove or cannals, and other works, that estimating volume plan and costs are able to predict the real condition.

The $F$ value is about 6.64 that is categorized in to diurnal tide where there is one of low water and one of high water tide in a day. At the high tide, the highest amplitude is about $84.80 \mathrm{~cm}$ above MSL value $(96.20 \mathrm{~cm})$. Based on the data, it can be said that in 6 hours duration, there is a high tide over $0.5 \mathrm{~m}$ above MSL which is occurred during the afternoon. Conversely, the low tide is occored about 6 hours during midnight before dawn and the sea level raises happening during mid day. This condition provides information for fishermen of Pongok Island to go fishing bar-cheeked coral trout grouper in early morning and landing their boat safely at a high tide in the port near to their settlement in the afternoon. This condition will be happened for every day based on results data from this research.

In capture fishery, especially fish trap fishermen who catch bar-cheeked coral trout grouper, the availability bathymetry is an important information. Mapped coordinates and corrected bathymetries for the period of 12 months become a reference for those fishermen in diving to set and take up their fishing traps with measured time duration and being a referenced fishing grounds. By changing months and years, those fishermen are able to go fishing in the fishing grounds repeatedly and those fishing grounds are coral reef areas that have many fish. For the grouper fishermen, recorded coordinate spots and bathymetry have proven as fishing grounds and become key in operating their business. Based on the information, setting and taking up fish traps are hopped optimally catching many fish. Results of interviews to the fishermen indicate that before they utilized GPSmap, they only relied on signs of nature as their benchmark to find diving spots, consequently, their catch also were less. After using the GPSmap, time duration to locate their coordinate spots in setting fish traps is quickly and accurately, and becomes knowledge for the fishermen in determining their fishing grounds. The fishermen set two fish traps in each coordinate spot with 4-6 days of soaking duration and then those fishing trap are taken up, and after that they reset their traps in new locations based on their experiences which are proven having many fish. Having some bathymetry spots (Figure 2.) is one of initial capitals beside physical strength in diving. They have to estimate how deep can be dived safely to prevent fatal risks such as decompressions that can be deadly. Based on corrected bathymetry calculation (Table 5.) is known that average of fishermen dive about 14.66-22.46 $\mathrm{m}$ depths in fishing grounds, however overall minimum and maximum depth are 4.20 and 40.80 $\mathrm{m}$, respectively. There is a quite significant deviation between corrected and uncorrected bathymetry values. For specific purpose that requires high accuracy, this matter becomes important. In Table 4, exhibits maximum $1.20 \mathrm{~m}$ of bathymetry deviation. For an example if this bathymetry value is combined to the quality analysis of coral reefs towards depths, can inflict a wrong interpretation.

The coordinates and value of bathymetry that have a good catch of fish are important for fisherman. Each of trap fisherman has own coordinate spots of diving in coral reef areas secretly for avoiding competitors to maintain security of their business and undesirable things. The fishing trap fishermen are related to safe bathymetry coordinates for diving, good coral reefs, not the cruise lines, and safe of stealing in setting fishing traps location are very valuable things for fisherman. Furthermore, based on collected data and intervewing fishing trap fishermen, a fisherman is able to dive by using compressor into $40.80 \mathrm{~m}$ depths to set and take up fish traps even though sometimes it is conducted by him self or alone. Scientifically, this is not allowed to dive alone, where a standard diving requires two divers or a buddy. Diving alone for fishing by using a compressor has been a habitual for the fishermen eventhough they really know it has a high risk work. To dive into $\pm 20 \mathrm{~m}$ depth, fisherman needs $10-15$ minutes to reach sea floor and taking fish traps up to sea surface. The average bathymetry value each month can be a clue to catching reef fish in the coral reef ecosystem. Diving to catch fish with an average depth of 14.7 to $22.5 \mathrm{~m}$ gives a high catch with a very high risk. These bathymetry values can serve as a reference for coral reef fishing sites in coral reef ecosystems in order to make fisherman catches profitable.

\section{Conclusions}

Values of mean sea level, chart datum, and $\mathrm{F}$, are $0.96 \mathrm{~m}, 0.05 \mathrm{~m}$, and 0.07 , respectively. These values indicate a diurnal tide, Bench Mark 
(BM) of Celagen Island on the coordinate of $02^{\circ} 52$ '26.4"S and $107^{\circ} 00^{\prime} 58.5^{\prime \prime} \mathrm{E}$ with BM height of $3.16 \mathrm{~m}$ above ground level of a scale pole. Correction of bathymetry towards values of bathymetry during survey results a maximum deviation about $1.2 \mathrm{~m}$ from the measured depth value during the field survey. Mapping corrected bathymetry gives information with regard to a bathymetry value that is able to be adopted in to sea maps as a depth reference in coral reefs areas which become fishing grounds of fishermen, this bathymetry value can complement the bathymetry value for the area around the Lepar Island and the Pongok Island on the sea map from Dishidros. Average bathymetry for managing the fishing grounds of coral reef fish is in ranged of 14.66 to $22.46 \mathrm{~m}$ depths. These bathymetry values can serve as a reference for coral reef fishing sites in coral reef ecosystems in order to make fisherman catches profitable.

\section{References}

Adibrata, S. 2007. Tides analysis in the Karampuang Island, West Sulawesi Province. Akuatik 1(1): 1-6.

Allen, G. 1999. Marine fishes of South-East Asia. Asia-Pasific Berkeley Book Pte Ltd. Tai Seng Avenue. Singapore. 534167.

Bangka Belitung Ocean Science and Technology Center [BOST]. 2017. Tides data for September 2017. Pangkalpinang.

Blaber, S.J.M., Brewer, D.T. \& Harris, A.N. 1994. Distribution, biomass, and community structure of demersal fishes of the Gulf of Carpentaria, Australia. Austra. J. Mar. Freshwat. Res. 45(3): 375-396. doi: 10.10 71/MF9940 375.

Bradshaw, E., Woodworth, P.L., Hibbert, A., Bradley, L.J., Pugh, D.T., Fane, C. \& Bingley, R.M. 2016. A Century of Sea Level Measurements at Newlyn, Southwest England. Mar. Geodesy. 39 (2): 115-140.

Froese, R. \& Pauly, D. 2017. FishBase. World Wide Web electronic publication. www.fishbase. org.

Garner, S.B \& Patterson, W.F. 2015. Direct observation of fishing effort, catch, and discard rates of charter boats targeting reef fishes in the northern Gulf of Mexico. Fish. Bull. 113: 157-166. doi: 10.7755/FB.113. 2.4.

Giordano, F., Mattei, G., Parente, C., Peluso, F. \& Santamaria, R. 2016. Integrating sensors into a marine drone for bathymetric 3D surveys in shallow waters. Sensors, 16(41): 1-17.

International Hydrographic Organization [IHO]. 2005. Manual on Hydrography (C-13 1st ed). International Hydrographic Bureau. Monaco.

International Hydrographic Organization [IHO]. 2017. Regulation of the IHO for international (int) charts and chart specifications of the IHO. International Hydrographic Bureau. Monaco.

Nandiko, R. 2017. Measurement of depth of seabed and sea flow rate under Suramadu Bridge Madura side for determination of mooring turbine construction sea power plants. J. Ocean. Mecha. Aero. Sci. Eng. 43(1): 7-13.

Ongkosongo, O.S.R. \& Suyarso. 1989. Tides. P30 LIPI. Jakarta.

Pradipta, N.D., Prasetyo, Y. \& Wijaya, A.P. 2015. Tides analysis used of data IOC (Intergovernmental Oceanographic Comission) for determining chart datum in Cilacap waters. J. Geodesi Undip. 4(2): 101-109.

Pugh, D.T. 1996. Tides, Surges and Mean Sea Level. John Wiley and Sons. New York.

Rami, A., Nechimi, M., Maarouf, S. \& Benkouider, T. 2016. Tidal Signal Processing by Harmonic Analysis for the Algerian Vertical Reference Determination. Athens. ATINER'S Conference Paper Series, No: MDT2016-1898.

[RI Act No. 4] Republic of Indonesia Act. 2011. Geospasial information. Jakarta.

Tamisiea, M.E., Hughes, C.W., Williams, S.D.P. \& Bingley, R.M. 2014. Sea level: measuring the bounding surfaces of the ocean. Philosophical Trans. Royal Soc. London A. 372: 20130336. doi:10.1098/rsta.2013.0336.

Tupper, M. 2007. Identification of nursery habitat for commercially valuable humphead wrasse Cheilinus undulates and large groupers (pisces: serranidae) in Palau. Mar. Ecol. Prog. Ser. 332: 189-199.

Witjaksono, A., Wibisono, A. \& Setiawan, A. 1989. Tides Prediction Software V1.002. BPPT. Jakarta.

Yamasaki, S., Tabusa, T. Iwasaki, S. \& Hiramatsu, M. 2017. Acoustic water bottom investigation with a remotely operated watercraft survey system. Prog. Earth Planet. Sci. (4)25: 1-9. doi: 10.1186/s40645-017-0140-y 